REPORTS OF MORPHOLOGY
Official Journal of the Scientific Society of Anatomists,
Histologists, Embryologists and Topographic Anatomists
of Ukraine
journal homepage: https://morphology-journal.com

\title{
Histological picture in the skin of rats within a month after burn II-III degree against the background of the introduction for first 7 days $0.9 \% \mathrm{NaCl}$ solution
}

\section{Mironov Ye.V.}

National Pirogov Memorial Medical University, Vinnytsya, Ukraine

\section{ARTICLE INFO}

Received: 26 August, 2019

Accepted: 30 September, 2019

UDC: $616-001.17: 615.451 .3$

CORRESPONDING AUTHOR

e-mail: dgekets@gmail.com Mironov Ye.V.

\begin{abstract}
Burn disease is a complex of pathological changes that occur in the body due to the action of a thermal agent and are life-threatening. The problem of skin burns still remains relevant today. Insufficiently studied features of pathogenesis and methods of treatment of thermal trauma are the cause of considerable interest of scientists in this problem. The aim is to study the features of microscopic changes in the skin of rats during the month after grade II-III burn on the background of the introduction of the first 7 days of $0.9 \% \mathrm{NaCL}$ solution. The studies were performed on 360 laboratory white male rats weighing 155-160 g. During the experiment, the animals were divided into 4 groups: 1st, 2nd groups - rats without thermal trauma infused with $0.9 \% \mathrm{NaCl}$ solution and HAES-LX-5\% at a dose of $10 \mathrm{ml} / \mathrm{kg}$. In the $3 \mathrm{rd}$, 4th groups, rats were infused with $0.9 \% \mathrm{NaCl}$ solution and HAES-LX-5\% at a dose of $10 \mathrm{ml} / \mathrm{kg}$ after skin burns. Burning skin damage was caused by applying to the lateral surfaces of the trunk of rats for 10 seconds four copper plates, heated in water at a constant temperature of $100^{\circ} \mathrm{C}$. Histological preparations were prepared by standard procedure and examined using an OLYMPUS BH-2 light microscope. Conducted microscopic studies of the skin of animals after thermal trauma under the conditions of application of $0.9 \% \mathrm{NaCl}$ solution found that in the early stages of the experiment $(1,3,7$ days) compensatory and adaptive changes of its structural components are combined with signs of destructive disorders. In the later periods of thermal trauma (14, 21 and 30 days), the destructive changes of the structural components of the skin in the lesion area deepen, and the process becomes irreversible.
\end{abstract}

Keywords: skin burns, histological changes, necrosis, $0.9 \% \mathrm{NaCL}$ solution.

\section{Introduction}

Despite the significant advances in modern medicine and the improvement of methods of diagnosis and treatment, the problem of skin burns is still relevant today. Scientists have linked this fact to an increase in the frequency of burns in the home, at work, and in connection with military regional conflicts [13, 20, 21, 23]. In addition, the question remains regarding the features of the pathogenesis of burn disease and its treatment $[3,6,12]$. Special attention of scientists to thermal skin damage is also explained by the fact that it leads to considerable complications and mortality $[9-11,18,22]$.

In recent years, the methods of treatment of thermal trauma have been significantly improved, but in most cases and today assistance to patients with severe burns consists in the direct treatment of local skin lesions, despite the well-known fact that the pathogenesis of the acute period of burn disease lies in systemic disorders $[3,4,6,12,15-$ $17,19]$. Therefore, the problem of thermal trauma is multifaceted, requires a comprehensive solution and a more detailed study of the features of its course.

\section{Materials and methods}

The studies were performed on 360 laboratory white male rats weighing $155-160 \mathrm{~g}$. During the experiment, the animals were divided into 4 groups: 1 st, 2 nd groups - rats without thermal trauma infused with $0.9 \% \mathrm{NaCl}$ solution and HAES-LX-5\% at a dose of $10 \mathrm{ml} / \mathrm{kg}$. In the 3rd, 4th groups, rats were infused with $0.9 \% \mathrm{NaCl}$ solution and HAES-LX-5\% at a dose of $10 \mathrm{ml} / \mathrm{kg}$ after skin burns. Burning skin damage was caused by applying to the pre-depilated lateral surfaces of the trunk of rats for 10 seconds four copper plates (two plates on each side, each with a surface 
area of $13.86 \mathrm{~cm}^{2}$ ), which were pre-heated for 6 minutes in water at a constant temperature of $100^{\circ} \mathrm{C}$. [1, 7]. The total area of skin lesion in rats was $21-23 \%$. All solutions were introduced into the inferior vena cava after catheterization under aseptic conditions through a femoral vein at a dose of $10 \mathrm{ml} / \mathrm{kg}$ body weight of the animal. Shaving of the lateral surfaces of rats' trunk, catheterization of veins, staging of skin burns, and decapitation of animals were performed under intravenous propofol anesthesia (calculated at $60 \mathrm{mg} / \mathrm{kg}$ body weight). For further in-depth study, we selected skin changes at 1,3 , and 7,1421 , and 30 days from the start of the experiment. For histological examination, skin fragments were fixed in $10 \%$ neutral formalin solution, washed in running water, dehydrated in a battery of alcoholic solutions of increasing concentration, and enclosed in a steamer [8]. Sections 4-6 $\mu \mathrm{m}$ thick were made on a rotary microtome, placed on slides, stained with eosin hematoxylin after standard wiring, and poured into Canadian balm. Histological specimens were examined in an OLYMPUS BH-2 light microscope using $\times 10$ and $x 40$ lenses and $\mathrm{x} 10$ eyepieces.

\section{Results}

In rats which, after thermal burns of the skin, a $0.9 \%$ solution of $\mathrm{NaCl}$ at a dose of $10 \mathrm{ml}$ per $\mathrm{kg}$ was injected, after 1 day the structural signs of the condition of the burn wound indicate burn IIB degree. In the affected area of the skin revealed coagulation necrosis of the epidermis and dermis, and in the hypodermis, there were signs of edema.

In the epidermis, the layered organization of keratinocytes is impaired, necrobiotic changes are present, cell boundaries are not visualized. The intercellular spaces between the epidermocytes are enlarged. The basement membrane is loosened, the collagen fibers in it are destructed, there are areas of detachment of the epidermis

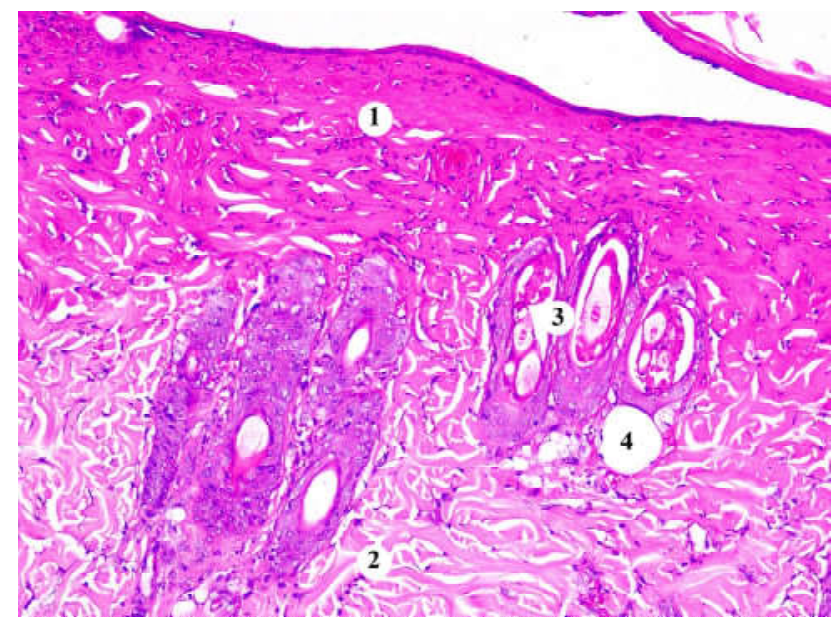

Fig. 1. Histological changes in the skin of the rats 1 day after burn, which was administered $0.9 \% \mathrm{NaCl}$ solution: 1 - coagulation necrotizing epidermis and papillary layer of the dermis, 2 - mesh layer of the dermis, 3 - destructively altered skin appendages, 4 - enlarged lymphatic capillary. Staining with hematoxylin and eosin. x200. from the dermis, which leads to disruption of its barrier function.

In this period of experiment, there is swelling of the papilla and mesh layers of the dermis and their infiltration by leukocytes. The papillary layer of the dermis in the burn area is smoothed, without well-defined papillae. The luminescence of the vessels of the hemomicrocirculatory bed within the burn wound of the skin is considerably enlarged, full-blooded, containing blood clots. There was pronounced interstitial swelling and hemorrhage around the hemocapillaries. The lymphatic capillary glands were enlarged, containing lymph and blood cells. Collagen fibers around the lymphatic capillaries are homogenized. Also revealed disorders of blood circulation, in the form of stasis, marginal standing and diapedesis of leukocytes through the walls of the blood vessels of the circulatory microcirculatory bed, as well as plasmorrhagia. The epitheliocytes of the hair follicles and sebaceous glands in the burn zone are necrobiotically and dystrophically altered (Figs. 1, 2).

In rats which, after thermal burns of the skin, $0.9 \% \mathrm{NaCl}$ solution was injected after 1 day also showed dystrophic changes in skin areas located on the border with the burn zone. In the spinous layer of the epidermis, the interepithelial spaces are enlarged. The lymphocyte count is increased in all layers of the epidermis.

In the dermis of the marginal area of the wound there is no differentiation into papillary and mesh layers. Collagen fibers with signs of edema, blood vessels full-blooded (Fig. 3).

Histologically, for 3 days of the experiment in the group of animals with burns and the introduction of $0.9 \% \mathrm{NaCl}$ solution in the central and peripheral areas of the wound, destructive changes associated with tissue necrosis increase. The keratinocytes of all layers of the epidermis are damaged, in many cells pyknosis and karyorrhexis of

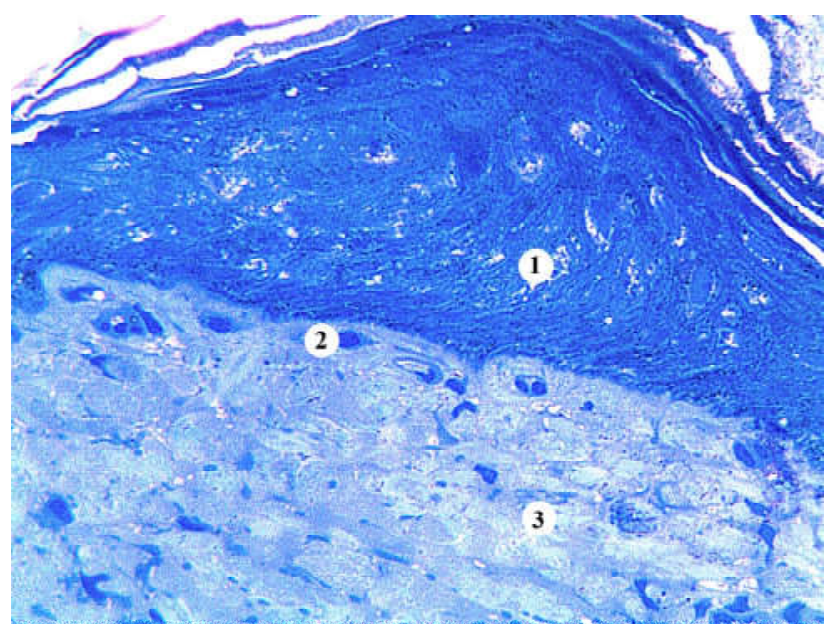

Fig. 2. Microscopic changes in the skin of the rat, 1 day after burn, which was administered $0.9 \% \mathrm{NaCl}$ solution: 1 - necrotized epidermis, 2 - hemostasis in the capillary, 3 - coagulated collagen fibers of the dermis. Semi-thin section. Methylene blue staining. $\mathrm{x} 400$. 


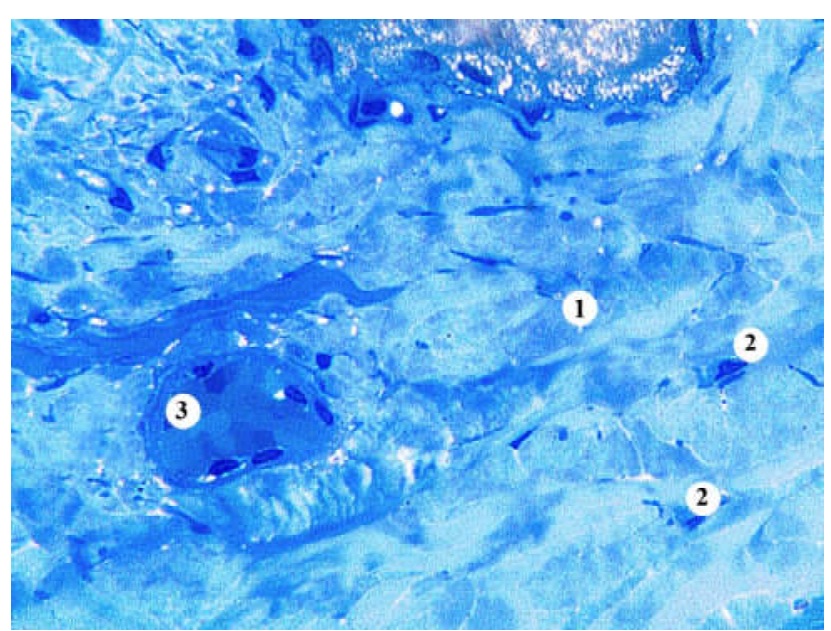

Fig. 3. Microscopic changes in the skin of the rat, 1 day after burn, which was administered $0.9 \% \mathrm{NaCl}$ solution: 1 - swollen collagen fibers, 2 - fibrocytes, 3 - hemostasis in the enlarged capillary. Semi-thin section. Methylene blue staining. $\times 400$.

the nuclei are present (Fig. 4).

Fibroblasts, numerous rod-like neutrophils, eosinophils, macrophages, lymphocytes, and a considerable number of tissue basophils with phenomena of degranulation are present around and in the center of the damage zone among fibrous connective tissue structures. Most cells of the hair follicles and sebaceous glands are dystrophically altered. The blood vessels of the blood and lymphatic vessels are enlarged, sometimes with a stasis of shaped elements in their lumen.

Perifocal formation of the epidermal wedge is observed, in which most of the cells are in a state of dystrophy or destroyed. In numerous places, it is detached from connective tissue, and there are hemorrhages underneath (Fig. 5).

Microscopically for the 7th day of the experiment under the conditions of introduction of $0.9 \% \mathrm{NaCl}$ solution, the burn area is covered by a scab, formed from the destroyed epidermocytes, fibrin, and blood cells. In many areas, the crust goes far beyond the damage and covers a somewhat thickened layer of the epithelium. In such places, the epidermis is deformed, sometimes in the form of an amorphous mass, densely infiltrated by cellular detritus, neutrophils, and macrophages.

In the papillary layer of the dermis, lesions of the collagen fibers are homogenized, eosinophilic, leukocyte infiltrated, among which rod-core neutrophils prevailed. Epithelial cells composed sheath of hair follicles are in a state of necrosis. All these altered structures form a rough solid crust that is closely soldered to the underlying mesh layer of the dermis. A demarcation shaft (Fig. 6) is located between the bark and the preserved part of the dermis. The luminescence of blood vessels contained blood clots, hemorrhages were found around the vessels.

At the periphery of the burn wound, the epidermis is

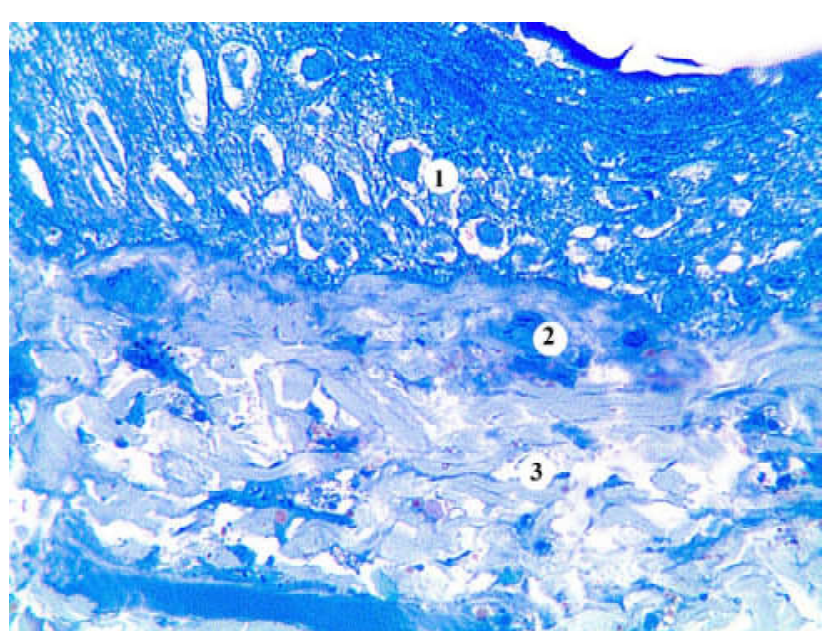

Fig. 4. Microscopic changes in the skin of the rat, 3 days after burn, which was administered $0.9 \% \mathrm{NaCl}$ solution: 1 - necrotized keratinocytes of the epidermis, 2 - damaged and blood-filled capillaries, 3 - fragmented collagen fibers. Semi-thin section. Methylene blue staining. $\times 400$.

hypertrophied, with the formation of single new capillaries due to the proliferation of endothelial cells in their walls. The gaps of most hemocapillaries are enlarged with dystrophic and necrobiotic altered endothelial cells. Hemorrhage,

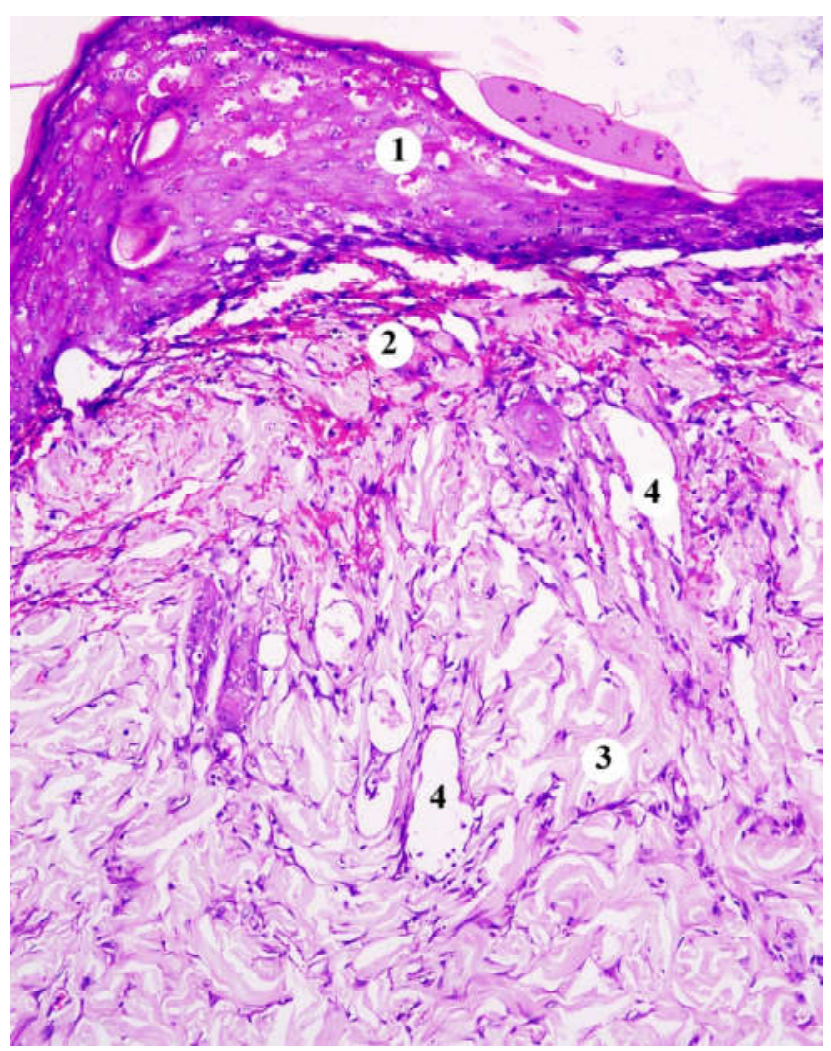

Fig. 5. Histological changes of the marginal area of the wound at 3 day after burn, with the introduction of $0.9 \% \mathrm{NaCl}$ solution: 1 epidermal wedge, 2 - hemorrhage in the papilla of the dermis, 3 mesh layer of the dermis, 4 - enlarged lymphatic capillaries. Staining with hematoxylin and eosin. $x 100$. 


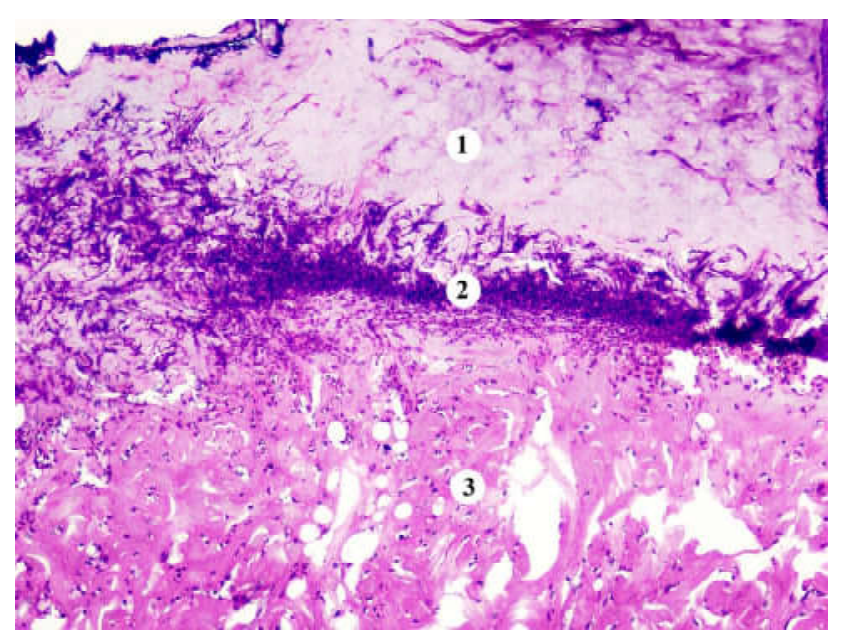

Fig. 6. Histological changes of the central area of the wound for 7 days after burn, with the introduction of $0.9 \% \mathrm{NaCl}$ solution: 1 scab, 2 - demarcation shaft, 3 - damaged and infiltrated leukocytes of the fiber of the mesh layer of the dermis. Staining with hematoxylin and eosin. x200.

leukocyte infiltration and pronounced interstitial edema are found around the vessels.

Microscopically, for 14 days after thermal trauma under the conditions of introduction of $0.9 \% \mathrm{NaCl}$ solution in the

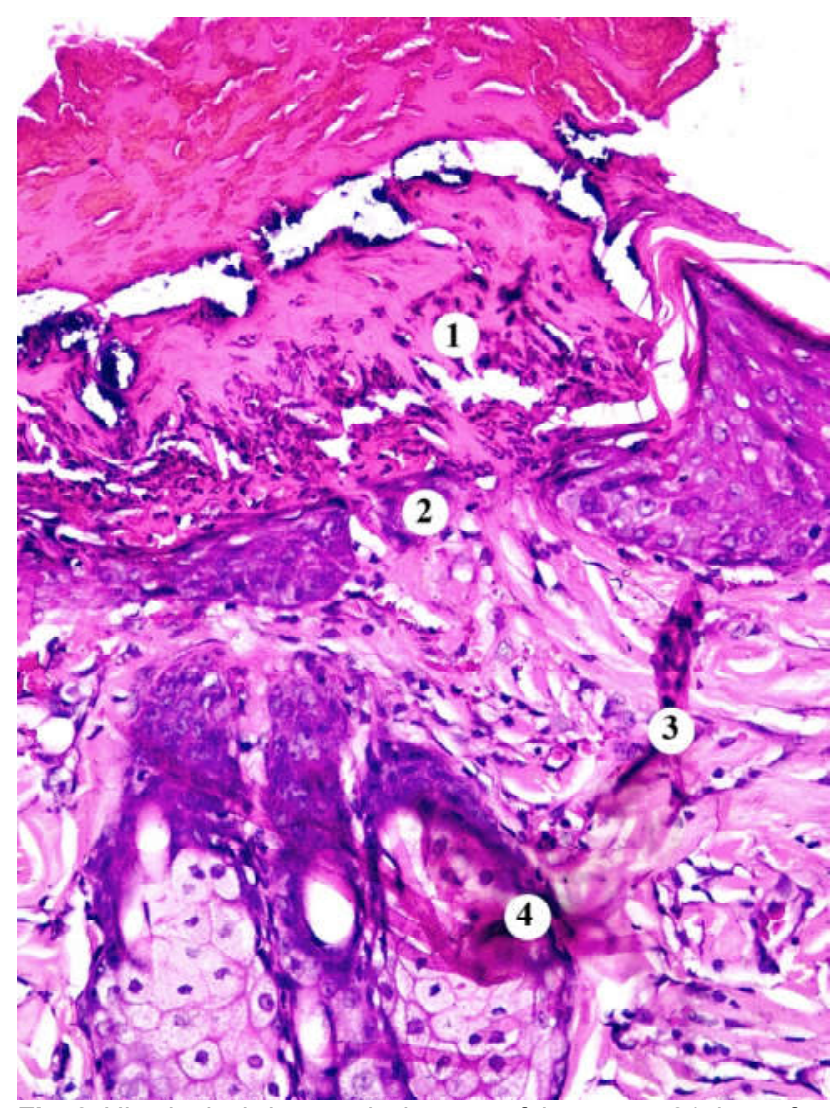

Fig. 8. Histological changes in the area of damage at 21 days after burn, with the introduction of $0.9 \% \mathrm{NaCl}$ solution: 1 - scab, 2 epithelial regenerate, 3 - dermis, 4 - skin appendages. Staining with hematoxylin and eosin. $x 200$.

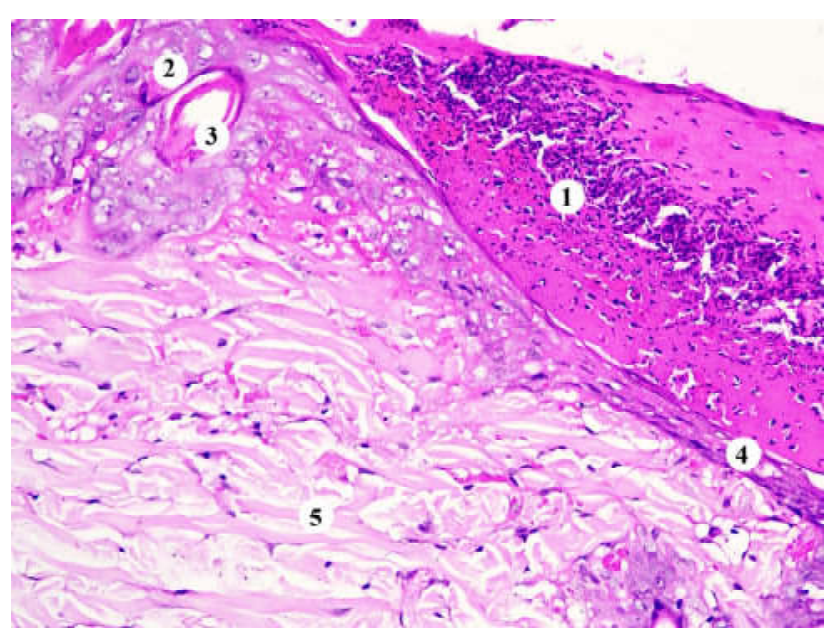

Fig. 7. Histological changes of the lesion site at 14 days after burn, with the introduction of $0.9 \% \mathrm{NaCl}$ solution: 1 - scab, 2 - thickening of the epidermis, with the participation of 3 - hair roots, 4 - epithelial regenerate, 5 - dermal collagen fibers. Staining with hematoxylin and eosin. $\times 200$.

wound area, a dense scab with a clearly limited area of necrosis was observed. Under the scab revealed areas of suppuration and a thin layer of epidermal regenerate, in which there is no layered differentiation of keratinocytes. The bottom of the wound is filled with a dense connective tissue that contains parallel directed bundles of collagen fibers between which are isolated single fibroblasts. The number of blood capillaries was lower than in the previous study period.

In the peripheral areas of the wound present expressed marginal epithelialization, epithelial heel in the form of a wedge grows under the scab. In the marginal areas, the wounds in the epidermis were differentiated between the basal, spinous, granular and stratum corneum layers. In the dermis of the skin, the papillary and mesh layers are poorly differentiated, the papillae are smoothed (Fig. 7).

On the 21st day after thermal trauma, the animals of this experimental group had a scab exfoliation. The epithelialization of the wound is more pronounced than in the previous study, but incomplete. In the center of the burn wound, areas of the epithelial layer were identified as a wedge, in which no differentiation into layers was evident (Fig. 8).

The formed connective tissue of the dermis lacks hair follicles and sebaceous glands. Leukocyte infiltration and slight interstitial edema are present around the vessels. In the newly formed connective tissue at the bottom of the wound, collagen fibrils have a parallel direction to the skin surface, and the blood capillaries are located along the fibers, indicating the maturation of the newly formed granulation tissue in the deep layers of the wound. The lumen of the lymphatic vessels is widened (Fig. 9).

In rats, which after the burn of the skin for 7 days was injected with $0.9 \% \mathrm{NaCl}$ solution, for 30 days of the study the wound is covered with a layer of epidermis. The papillary 


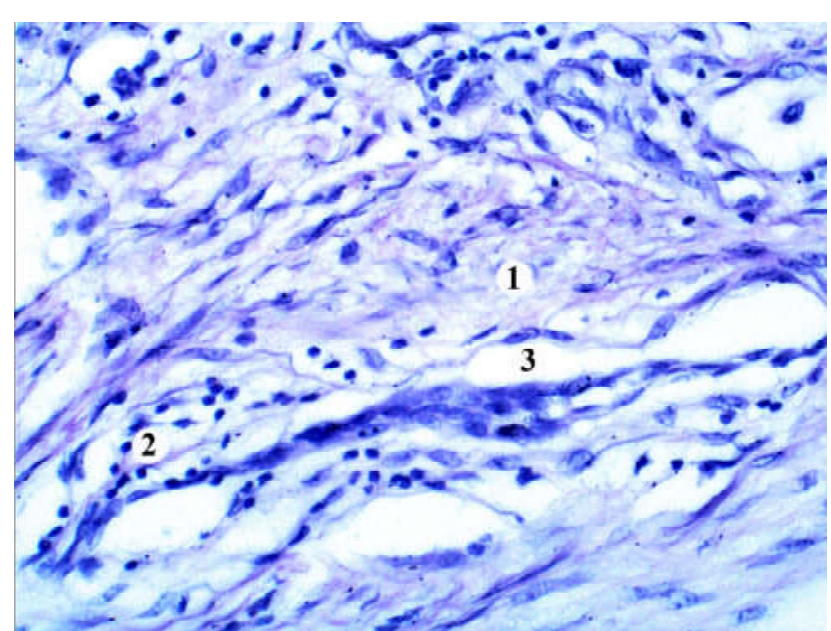

Fig. 9. Microscopic changes of rat skin dermis for 21 days after burn, with $0.9 \% \mathrm{NaCl}$ solution administration: 1 - collagen fibrils, 2 - leukocyte infiltration, 3 - lymphatic capillary. Semi-thin section. Methylene blue. $\times 200$

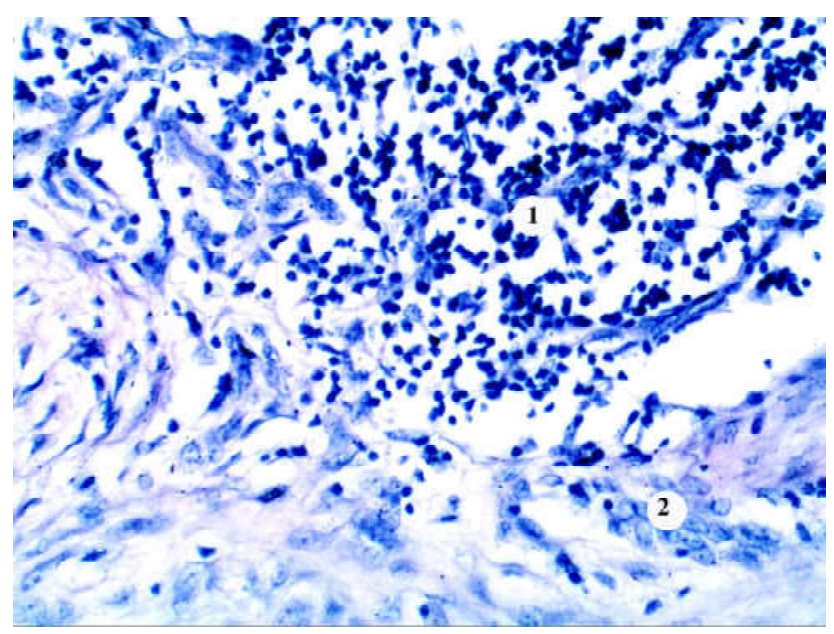

Fig. 11. Microscopic changes of the dermis of rat skin for 30 days after burn, with the introduction of $0.9 \% \mathrm{NaCl}$ solution: 1 - leukocyte infiltration, 2 - fibroblasts. Semi-thin section. Methylene blue stain. x200.

dermis is smoothed, the papillae are not expressed. The formed connective tissue of the dermis lacks hair follicles and sebaceous glands, few fibroblasts and vessels (Fig. 10).

In single fields of view revealed foci of leukocyte infiltration. As a rule, such foci were located around the vessels of the circulatory microcirculatory bed (Fig. 11).

\section{Discussion}

Experiment data on the effect of $0.9 \% \mathrm{NaCl}$ solution on the features of microscopic changes of organs and tissues in different terms of burn disease are associated with the results of our histological examination. In particular, it was found that the introduction of it to rats during the first 7 days after thermal injury of the skin did not prevent the development of dystrophic and destructive changes in the spleen. On the

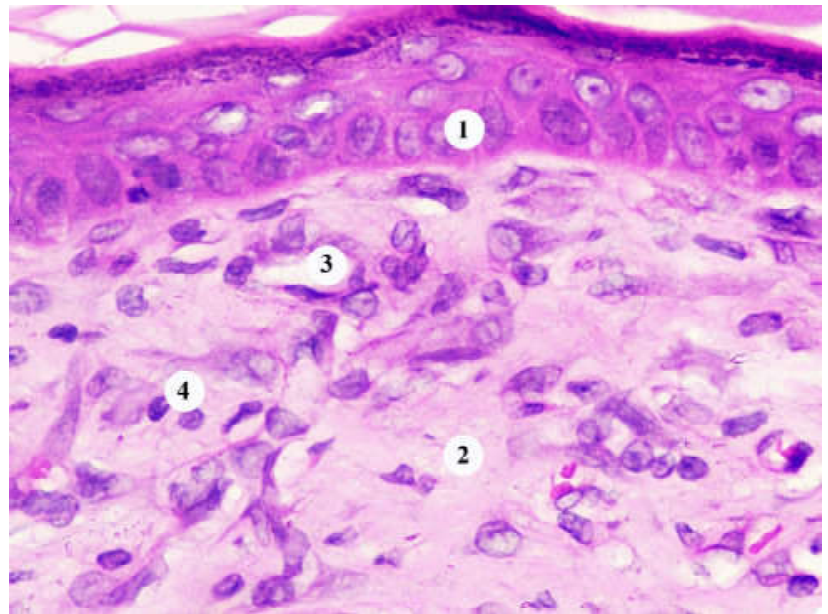

Fig. 10. Histological organization of the skin healing area of the rat for 30 days after burn, with the introduction of $0.9 \% \mathrm{NaCl}$ solution: 1 - epidermis, 2 - dermis, 3 - capillary, 4 - lymphocytes. Staining with hematoxylin and eosin. $x 400$.

1st day after burn revealed dystrophic processes in lymphocytes and macrophages, plethora of sinusoidal vessels of the spleen, swelling and infiltration of perivascular connective tissue. After 3 days, the process was deepened by the destruction of the periarterial zones, germination centers, and marginal areas of the white pulp [2].

In the adrenal cortex in the early periods after skin burns $(1,3,7$ days) with the introduction of $0.9 \% \mathrm{NaCl}$ solution revealed a combination of processes of destruction and compensatory changes, while at 14, 21 and 30 days further development and deepening lesions of all structural components of the organ cause the development of irreversible changes [5].

Histological examination of the structure of the lungs at day 14 after skin burn under the conditions of the first 7 days of $0.9 \% \mathrm{NaCl}$ solution revealed disorders of microcirculation in the respiratory department, thickening of the interalveolar septa due to infiltration by their lymphocytes and macrophages. After 30 days, there were signs of pneumosclerosis, destruction, and no compensation for pathological changes, indicating their irreversibility [14].

Available data on the effect of infusion of $0.9 \% \mathrm{NaCl}$ solution under conditions of thermal injury on the transformation of the intercellular substance of the internal organs. It is established that on 1, 3, 7 and 14 days after skin burns, there is a development of cell alteration and intercellular edema. Under these conditions significant changes undergo the vessels of the microcirculatory bed, which are manifested in the form of progressive thinning of endothelial cells, their microclasmatosis and even necrosis [4].

\section{Conclusions}

1. Conducted microscopic studies of the skin of animals after thermal trauma under the conditions of application of $0.9 \% \mathrm{NaCl}$ solution found that in the early stages of the experiment (1, 3, 7 days) compensatory and adaptive 
changes of its structural components are combined with signs of destructive disorders. In the epidermis of the affected area of the skin there is destruction of the epitheliocytes of all its layers. Vascular disorders in the dermis are combined with changes in fibroblasts, homogenization and swelling of the components of the intercellular substance.

2. In the late stages of the experiment $(14,21$ and 30

\section{References}

[1]Abdullahi, A., Amini-Nik, S., \& Jeschke, M. G. (2014). Animal models in burn research. Cell Mol. Life Sci., 71(17), 3241-3255. doi: 10.1007/s00018-014-1612-5

[2] Bebeshko, N. P. (2013). Dynamics of morphological changes in the spleen of rats at 1, 3 and 7 days after skin burn with the introduction of saline $\mathrm{NaCL}$ or lactoprotein with sorbitol. Ukrainian Medical Almanac, 16(3), 12-18.

[3] Butcher, M., \& Swales, B. (2012). Assessment and management of patients with burns. Nurs Stand., 27(2), 50-55. doi: 10.7748/ ns2012.09.27.2.50.s52

[4] Cherkasov, V. G., Gunas, I. V., Kovalchuk, A. I., Dzevulska, I. V., Cherkasov, E. V., Malykov, A. V. ... Matkyvskaia, R. M. (2015). Ultrastructural transformations of the intercellular substance in the internal organs in the treatment of burn disease by infusion of combined hyperosmolar solutions. Clinical Anatomy and Surgical Surgery, 14(1), 37-44.

[5] Dzevulska, I. V. (2015). Monthly dynamics of the ultrastructural changes of the adrenal glands of rats after thermal injury of the skin under the conditions of the first seven days of $0.9 \% \mathrm{NaCl}$ solution. World of medicine and biology, 3(52), 91-98.

[6] Guilabert, P., Usua, G., Martin, N., Abarca, L., Barret, J. P., \& Colomina, M. J. (2016). Fluid resuscitation management in patients with burns: update. Br. J. Anaesth., 117(3), 284-296. doi: 10.1093/bja/aew266

[7] Gunas, I., Dovgan, I., \& Masur, O. (1997). Method of thermal burn trauma correction by means of cryoinfluence. Abstracts are presented in zusammen mit der Polish Anatomical Society with the participation of the Association des Anatomistes Verhandlungen der Anatomischen Gesellschaft, Olsztyn ( $\mathrm{p}$. 105). Jena - München: Der Urban \& Fischer Verlag.

[8] Horalskyi, L. P., Khomych, V. T., \& Kononskyi, O. I. (2011). Fundamentals of histological technique and morphofunctional methods of research in normal and pathology. Zhytomyr: Polissya.

[9] Hur, J., Yang, H. T., Chun, W., Kim, J., Shin, S., Kang, H. L., \& Kim, H. S. (2015). Inflammatory cytokines and their prognostic ability in cases of major burn injury. Ann. Lab. Med., 35(1), 105-110. doi: 10.3343/alm.2015.35.1.105

[10] Kallinen, O., Maisniemi, K., \& Boheing, K. (2012). Multiple organ failure as cause of death in patients with severe burns. J. Burn Care Res., 33(2), 206-211. doi: 10.1097/ BCR.0b013e3182331e73

[11] Klychnykova, E. V., Tazyna, E. V., Smyrnov, S. V., Spyrydonova, T. G., Zhyrkova, E. A., Borysov, V. S., \& Godkov, M. A. (2015). Interrelation of biochemical indicators of oxidative stress, endogenous intoxication and regulation of vascular tone in patients with burn injury. Anesthesiology and Intensive Care, (1), 45-49. days), the destructive changes of the structural components of the skin in the lesion area deepen. This process is irreversible. As a consequence, granulation and maturation occur slowly. The marginal epithelialization of the wound with the formation of a complete, differentiated into layers regenerate is also slowed. At the 30th day of the experiment, with the use of $0.9 \% \mathrm{NaCl}$ solution, no dermal papillae and skin appendages were present in the healing area.

[12] Kovalenko, O. M. (2014). Issues of infusion therapy for burn shock. Surgery of Ukraine, (2), 13-19.

[13] Kryzyna, P. S., \& Pysmenna, O. V. (2011). Pathomorphological changes in the burn wound. Ukraine, Nation's Health, 1(17), 93-97.

[14] Makarova, O. I. (2013). Histological picture of changes in the lungs of rats at 14, 21 and 30 days after thermal burn of the skin. Biomedical and Biosocial Anthropology, 21, 73-79.

[15] Masood, R. A., Wain, Z. N., Tariq, R., Ullah, M. A., \& Bashir, I. (2016). Burn Cases, Their Management and Complications: A Review. International Current Pharmaceutical Journal, 5(12), 103-105. doi: 10.3329/icpj.v5i12.30411

[16] Porter, C., Herndon, D. N., Bhattarai, N., Ogunbileje, J. O., Szczesny, B., Szabo, C. ... Sidossis, L. S. (2015). Severe Burn Injury Induces Thermogenically Functional Mitochondria in Murine White Adipose Tissue. Shock, 44(3), 258-264. doi: 10.1097/ SHK.0000000000000410

[17] Rowan, M. P., Cancio, L. R., Elster, E. A., Burmeister, D. M., Rose, L. F., Natesan, S. .. \& Chung, K. K. (2015). Burn wound healing and treatment: review and advancements. Crit. Care, (19), 112. doi: 10.1186/s13054-015-0961-2

[18] Saraf, M. K., Herndon, D., N., Porter, C., Toliver-Kinsky, T., Radhakrishnan, R., Chao, T. ... Sidossis, L. S. (2016). Morphological Changes in Subcutaneous White Adipose Tissue After Severe Burn Injury. J. Burn Care Res., 37(2), 96-103. doi: 10.1097/BCR.0000000000000292

[19] Szczesny, B., Brunyanszki, A., Ahmad, A., Olah, G., Porter, C., Toliver-Kinsky, T. ... Szabo, C. (2015). Time-Dependent and Organ Specific Changes in Mitochondrial Function, Mitochondrial DNAIntegrity, Oxidative Stress and Mononuclear Cell Infiltration in a Mouse Model of Burn Injury. PLOS ONE, 10(12), e0143730. doi: 10.1371/journal.pone.0143730

[20] Vons, B. V., Chubka, M. B., \& Groshovyi, T. A. (2018). The problem of burn injury treatment and drug characteristics for local burn treatment. Topical issues in pharmaceutical and medical science and practice, 11, 1(26), 119-125. https:/l doi.org/10.14739/2409-2932.2018.1.123731

[21] Yvchenko, E. V., Borysov, D. N., Golota, A. S., Krassyi, A. B., \& Rusev, I. T. (2015). Combined burns in the structure of modern civil and combat burn injury. Military Med. J., 336(2), 22-25.

[22] Zviahyntseva, T. V., Kryvoshapka, A. V., \& Myronchenko, S. I. (2010). Pro-inflammatory cytokines in the development of an experimental burn. Bulletin of the Higher Scientific-Educational Institution "Ukrainian Medical Dental Academy", 10(4), 78-82.

[23] Zviahyntseva, T. V., Kryvoshapka, A. V., \& Zhelnyn, E. V. (2014). The role of nitric oxide metabolites in the mechanisms of experimental burn development. Experimental and clinical medicine, 2(51), 5-9.

ГІСТОЛОГІЧНА КАРТИНА В ШКІРІ ЩУРІВ ПРОТЯГОМ МІСЯЦЯ ПІСЛЯ ОПІКУ ІІ-ІІІ СТУПЕНЯ НА ФОНІ ВВЕДЕННЯ ПЕРШИХ 7 ДІБ $0,9 \%$ РОЗЧИНУ NACL

Міронов Є.В.

Опікова хвороба - це небезпечний для життя комплекс патологічних змін, що виникає в організмі внаслідок дії термічного 
агенту. Проблема опіків шкіри досі залишається актуальною в наш час. Недостатньо вивчені особливості патогенезу та методи лікування термічної травми є причиною значної зацікавленості науковців даною проблемою. Метою роботи $\epsilon$ вивчення особливостей мікроскопічних змін в шкірі щурів протягом місяця після опіку II-ІІІ ступеня на фоні введення перших 7 діб 0,9\% розчину NaCL. Дослідження проведені на 360 лабораторних білих щурах-самиях масою 155-160 е. В ході експерименту тварин було розподілено на 4 групи: 1, 2 групи - щури без термічної травми, котрим проводили інфузію 0,9\% розчину $\mathrm{NaCl}$ та HAES-LX-5\% у дозі 10 мл/ке. У 3 та 4 групах щурам проводили інфрузію 0,9\% розчину NaCl та HAES-LX-5\% у дозі 10 мл/ка після опіку шкіри. Опікове пошкодження шкіри викликали шляхом прикладання до бічних поверхонь тулуба щурів на 10 секунд чотирьох мідних пластинок, нагрітих у воді з постійною температурою $100^{\circ} \mathrm{C}$. Гістологічні препарати готували за стандартною методикою та досліджували за допомогою світлового мікроскопа OLYMPUS BH-2. Проведені мікроскопічні

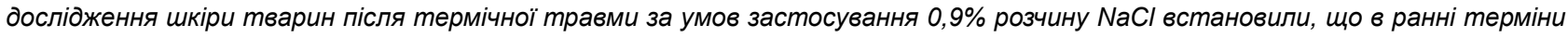
експерименту (1, 3, 7 доби) компенсаторно-пристосувальні зміни ї̈ структурних компонентів поєднуються з ознаками деструктивних порушень. У пізні періоди термічної травми (14, 21 та 30 доби) відбувається поглиблення деструктивних змін структурних компонентів шкіри у ділянці ураження, а процес набуває незворотного характеру.

Ключові слова: опіки шкіри, гістологічні зміни, некроз, 0,9\% розчин NaCL.

\section{ГИСТОЛОГИЧЕСКАЯ КАРТИНА В КОЖЕ КРЫС В ТЕЧЕНИЕ МЕСЯЦА ПОСЛЕ ОЖОГА ІІ-ІІІ СТЕПЕНИ НА ФОНЕ ВВЕДЕНИЯ ПЕРВЫХ 7 ДНЕЙ 0,9\% РАСТВОРА NACL \\ Миронов Е.В.}

Ожоговая болезнь - это опасный для жизни комплекс патологических изменений, возникающих в организме в результате действия термического агента. Проблема ожогов кожи до сих пор остается актуальной в наше время. Недостаточно изученные особенности патогенеза и методы лечения термической травмы являются причиной значительного интереса ученых к данной проблеме. Целью работы является изучение особенностей микроскопических изменений в коже крыс $в$ течение месяца после ожога II-III степени на фоне введения первых 7 дней 0,9\% раствора NaCL. Исследования проведены на 360 лабораторных белых крысах-самцах массой 155-160 2. В ходе эксперимента животные были распределены на 4 группы: 1 и 2 группы - крысы без термической травмы, которым проводили инфузию 0,9\% раствора NaCl и HAES-LX-5\% в дозе 10 мл/ка. В 3 и 4 группах после ожога кожи крысам проводили инфузию 0,9\% раствора NaCl и HAES-LX-5\% в дозе 10 мл/ ке. Ожоговое повреждение кожи вызвали путем приложения к боковым поверхностям туловища крыс на 10 секунд четырех медных пластинок, нагретых в воде с постоянной температурой $100^{\circ} \mathrm{C}$. Гистологические препараты готовили по стандартной методике и исследовали с помощью светового микроскопа OLYMPUS BH-2. Проведенные микроскопические исследования кожи животных после термической травмы в условиях применения 0,9\% раствора $\mathrm{NaCl}$ установили, что в ранние сроки эксперимента (1, 3, 7 суток) компенсаторно-приспособительные изменения ее структурных компонентов сочетаются с признаками деструктивных нарушений. В поздние периоды термической травмы (14, 21 и 30 суток) происходит углубление деструктивных изменений структурных компонентов кожи в области поражения, а процесс приобретает необратимый характер.

Ключевые слова: ожоги кожи, гистологические изменения, некроз, 0,9\% раствор NaCL. 